\title{
Was There a National Labor Market at the End of the Nineteenth Century? New Evidence on Earnings in Manufacturing
}

\author{
JOSHUA L. ROSENBLOOM
}

Average annual earnings calculated from the census of manufactures are used to extend previous research on labor market integration in the United States. In contrast to earlier research examining occupational wage rates, census average earnings indicate that a well-integrated labor market had emerged in the Northeast and North Central regions as early as 1879 . They also reveal substantial convergence within the South Atlantic and South Central regions, suggesting the emergence of a unified southern labor market. Large and persistent North-South differentials indicate, however, that a unified national labor market did not develop before World War I.

$\mathbf{H}$ istorically, the movement from localized markets to broader regional, national, or international markets has been an important factor in the process of economic development. In the United States, the dramatic growth of railroad and telegraph networks in the decades after the Civil War stimulated an especially rapid pace of economic integration, with profound effects on the structure of the economy. ${ }^{1}$ According to Alfred Chandler the falling cost of transportation and communication at this time was instrumental in the emergence of modern business enterprise. Responding to the opportunities created by falling transportation and communication costs, manufacturers in a wide range of industries expanded production and integrated vertically to serve national and international markets. ${ }^{2}$ At roughly the same time organized stock exchanges, commercial paper houses, insurance agents, mortgage brokers, and other

The Journal of Economic History, Vol. 56, No. 3 (Sept. 1996). (C) The Economic History Association. All rights reserved. ISSN 0022-0507.

Joshua L. Rosenbloom is Associate Professor, Department of Economics, University of Kansas, Lawrence, KS 66045 and Faculty Research Fellow, National Bureau of Economic Research.

I thank Tom Weiss, William Sundstrom, Gavin Wright, Peter Mancall, seminar participants at the University of Kansas, Stanford University, the University of California at Berkeley, and the University of California at Davis, and two anonymous referees for their comments. I am indebted to Robert Whaples and Tom Weiss for providing some of the data used in this research. Astrid Marschatz provided able research assistance. This research was supported in part by an Arthur Cole Grant in Aid from the Economic History Association and by University of Kansas General Research Allocation \#3094-20-0038.

${ }^{1}$ Between 1865 and 1900 railroad mileage in operation increased more than five-fold, rising from 35,000 to over 193,000. At the same time, the adoption of a standard gauge, improved coordination between lines, and a host of technological innovations-including larger engines, automatic couplers, and air brakes-increased the speed and lowered the costs of travel and transportation (Stover, American Railroads, pp. 143-80; and Taylor and Neu, American Railroad). These developments were paralleled by the growth and improvement of telegraph and telephone networks. See Field, "Magnetic Telegraph"; and Duboff, "Telegraph."

${ }^{2}$ Chandler, Visible Hand. 
financial intermediaries were expanding their role in the interregional mobilization of capital, contributing to the emergence of an increasingly integrated national financial market. ${ }^{3}$

In contrast to the general consensus regarding the changing geography of product and financial markets, research on the scope of American labor markets in this period is incomplete and at least partially contradictory. Establishing the timing and extent of geographic integration in American labor markets after the Civil War is important for our understanding of American economic development. It is also important for labor and social historians interested in migration, the growth of organized labor, or the course of real wages. These issues can all be interpreted in terms of the interaction of market forces of supply and demand, but before this analysis can proceed, it is essential to know whether the relevant units of analysis in each case are local, regional, or national. ${ }^{4}$

In this article I use previously unexploited data on average earnings drawn from the census of manufactures to extend substantially previous research on labor market integration during the late nineteenth and early twentieth centuries. These data show that a well-integrated labor market had emerged in the Northeast and North Central regions of the country by 1879. Indeed they suggest that regional integration was at least as great as it is today, and possibly better. They also suggest that a second regionally integrated labor market was emerging within the South at this time, but that northern and southern labor markets remained largely isolated from one another. Finally, although strong connections appear to have existed between labor markets in the Mountain and Pacific regions and the rest of the country, labor market trends in these regions remained at least partially distinct from those in the East.

The crucial function of a market is to bring together sources of supply and demand. The efficiency that economists attribute to market processes of allocation thus depends critically, in the case of the labor market, on the formation of channels of communication linking employers and job seekers as well as institutions to facilitate the movement of job seekers in response to employment opportunities. Because it is difficult or impossible to observe the networks of communication and assistance through which labor markets operate, however, research on market integration must focus on the observable consequences of integration. Most tests of integration are derived from the "law of one price," which states that within an integrated market, the free flow of information and labor will ensure that wages (for the same type of labor, employed under the same conditions) at different locations will "tend to equality easily and quickly."

${ }^{3}$ Davis, "Investment Market"; James, Money; and Snowden, "Mortgage Rates."

${ }^{4}$ Wright, "Labor History," pp. 328-33.

${ }^{5}$ Cournot, quoted in Marshall, Principles, pp. 324-25. See also McCloskey, Extent, p. 6. The necessity to hold constant the conditions under which the work is performed arises because workers presumably seek to maximize their utility, rather than earnings. Locations that offer more advanta- 
Two obstacles must be confronted, however, in applying this criterion. The first problem is that there will always be costs of transportation, information, risk, and so on that drive a wedge between wages in one location and those in another. Integration is thus a matter of degree, rather than a dichotomous event, and it is necessary to establish an appropriate standard of measurement against which wage differentials can be compared. Such a metric will necessarily be comparative. The second problem arises from the need to compare homogeneous labor working under the same conditions. The available data never conform precisely to these standards, and it is necessary to consider the effects on earnings of potential labor heterogeneity and differences in locational characteristics before drawing conclusions about market integration.

Even if these problems with the application of the law of one price are addressed, it should be noted that the equalization of wages is necessary, but not sufficient, to establish the existence of an integrated market. On the one hand, large demand or supply shocks can produce temporarily large wage differentials even within a well-integrated labor market. In this case, however, migration from low- to high-wage areas should be evident, and, unless the shocks are persistent, the differentials should narrow over time reflecting this migration. On the other hand, it is conceivable that the balance of supply and demand conditions in two entirely isolated labor markets could produce equalization despite the absence of any real linkage between them.

Previous studies of labor market integration in the late nineteenth century have relied on comparisons of daily wage rates within narrowly defined occupations. This approach has the advantage of reducing the effects of heterogeneity in labor quality and working conditions, but it means that investigation has been restricted to that small segment of the labor force employed in occupations sufficiently ubiquitous that wage quotations could be obtained from a relatively large number of locations. In practice, this means that the data pertain primarily to skilled craftworkers in a few industries-mainly construction, metalworking, and job printing-that produced mostly for local markets. ${ }^{6}$ Wages in these occupations may not be representative of developments in manufacturing labor markets more generally, where unionization was less significant and product market competition greater. Moreover, the available occupational wage data typically rest on the records of only a small number of employers in each location and cover a restricted sample of locations and years. ${ }^{7}$

geous packages of conditions-better climate, lower risk of unemployment, and so on-would be preferred if wages were equal.

${ }^{6}$ Although wage data are also available for unskilled laborers, it seems likely that wage quotations for these workers were drawn from the records of the same establishments contributing the other data, and thus may not be representative of larger labor market forces.

${ }^{7}$ The major sources of data on occupational wage differentials for the late nineteenth century are U.S. Department of Commerce and Labor, Nineteenth Annual Report, referred to hereafter as the 
Finally, because the geographic and occupational coverage of the data changes from study to study (and sometimes even within a single study), it is difficult to compare results across studies.

The majority of the available occupational wage data for the late nineteenth century are drawn from cities across the Northeast and North Central regions of the country. Confusingly, however, they present a contradictory picture of geographic wage differentials within these regions. Analyzing wage data for 23 occupations in 12 large cities drawn from Bulletin 18 of the U.S. Department of Labor, I found a persistent real wage gap of more than 20 percent between the Northeast and North Central regions from 1870 to $1898 .^{8}$ In contrast, however, studies using data from the Aldrich Report and the Nineteenth Annual Report suggest that in 1890 real wages in the North Central region were only about 3 to 5 percent higher than in the Northeast. Although southern and western cities are both reasonably well represented in the Aldrich Report and Nineteenth Annual Report data, there is relatively little evidence on wage trends in these regions prior to 1890 . Both sources suggest similar patterns of variation in southern and western wages in 1890. Wages in the South Atlantic were consistently below those in other parts of the country, with most occupational wages about 20 percent lower than in the North. In the South Central region, wages of most skilled occupations appear to have been equal to or slightly higher than those in the North, but unskilled wages were generally below northern levels. In the Mountain and Pacific regions, real wages were typically about 20 percent above eastern levels. ${ }^{9}$ In contrast to the limited scope and changing coverage of the occupa-

Nineteenth Annual Report, covering 1890-1903; U.S. Congress, Retail Prices, commonly referred to as the Aldrich Report, covering 1890; U.S. Department of Labor, "Wages," referred to hereafter as Bulletin 18, covering 1870-1898; and U.S. Congress, Report, referred to hereafter as the Weeks Report, covering 1851 to 1880 . Efforts were made in each case to gather data from all parts of the country, but the Northeast and Midwest are most heavily represented, especially in the Bulletin 18 and Weeks Report data. All of these studies collected data from manufacturers' payroll records retrospectively and were thus limited to employers who had been in business and kept useable records over the time period under study. This constraint was especially binding where investigators sought to gather data for long periods of time, as was the case for the Bulletin 18 and Weeks Report studies. In the case of Bulletin 18, investigators restricted their sample to only those employers who had operated over the entire period from 1870 to 1898 . Consequently, in each city most occupations were represented by data from only a handful of employers. A priori, it is impossible to assess what if any biases this particular sample selection procedure may have introduced. For the Weeks Report, employers who had operated over only part of the time period covered were included, but this means that the sample of employers and locations representing each region was changing continually. For further discussion of these sources, see Long, Wages, pp. 7-12.

${ }^{8}$ Rosenbloom, "One Market?" Wage data from the period 1851 to 1880 from the Weeks Report analyzed by Coelho and Shepherd, "Regional Differences," also indicate relatively large differences in real wages between the North Central and Northeast. Using data for all six occupations covered by the Weeks Report data, they found that real wages in the East North Central were roughly 25 percent above the Middle Atlantic in 1880, whereas wages in the West North Central were approximately 12 percent above the Middle Atlantic at that date.

"Sundstrom and Rosenbloom, "Occupational Differences"; and Coelho and Shepherd, "Impact." Rosenbloom, "Occupational Differences," used the same data as Sundstrom and Rosenbloom, but 
tional wage data, average annual earnings calculated from the census of manufactures can be used to examine labor market integration among male manufacturing workers in a consistent sample of 100 or more cities in all parts of the country from 1879 through 1919. Both Clarence Long and Albert Rees made extensive use of census earnings data in their classic studies of the trend in wage levels during the late nineteenth and early twentieth centuries, but the patterns of geographic variation in census earnings data have not previously been examined. ${ }^{10}$ Although the census earnings data are not without their defects, they provide a valuable alternative to the occupational wage data that have been used previously. Together these two sources of data can be used to reinforce and supplement each other, adding substantially to our understanding of the history of the geographic integration of U.S. labor markets after the Civil War.

\section{CENSUS EARNINGS DATA}

Prior to 1880 the collection of population and manufacturing statistics was conducted by temporarily employed census marshals. Because these marshals were poorly trained and motivated, a number of observers have expressed doubts about the accuracy of the statistics they returned, especially as they pertained to the increasingly complex information requested of manufacturers. ${ }^{11}$ In an effort to improve the quality of the manufacturing statistics in the 1880 census, the Census Office assigned responsibility for the collection of manufacturing data in 279 principal cities and towns to a group of special agents knowledgeable about manufacturing conditions. Statistics for 100 of the largest cities canvassed by the special agents were reported separately in the published returns. Census officials believed that the data gathered by the special agents were substantially more accurate than those collected by regular census enumerators, and in subsequent censuses the number of cities for which special agents were assigned and statistics reported separately continued to expand.

Although the census of manufactures did not report the earnings of manufacturing employees, average earnings can be calculated from the census as the ratio of total wage payments to the average number of wage

found somewhat larger interregional differentials due to reliance on a cost of living deflator based only on retail food prices.

${ }^{10}$ Long, Wages; and Rees, Real Wages. See also Brisendon, Earnings. Long did discuss geographic variations in earnings across broad regional aggregates from 1860 to 1890 , but his results are not especially useful, because he considered only a few broad regions and did not make any attempt to adjust earnings for differences in the cost of living. Wilson, "Intercity," used census earnings data to examine the relationship between city size and earnings from 1889 to 1939 but did not explicitly consider patterns of geographic variation.

${ }^{11}$ Long, Wages, pp. 39-40. 
earners employed during the calendar year preceding the census. ${ }^{12}$ For 1889,1899 , and 1904, average employment and total wages were reported separately for men over 15 years of age, women over 15 , and children, making it possible to calculate separate earnings figures for each of these groups. Although the published returns for other years report average employment separately for these three age-sex categories, they provide only a single aggregate wage figure. ${ }^{13}$ For these years it is necessary to impute the earnings of male manufacturing workers on the basis of the age and sex composition of the manufacturing labor force and the earnings of women and children relative to adult men in the years that these data are available. $^{14}$

Despite a number of changes in census methods and coverage, it is possible to construct a consistent time series of observations on average earnings of male manufacturing wage earners in major cities throughout the United States beginning in 1879 and extending until at least 1919. I have collected data on employment and wages for all manufacturing industries combined in the 100 cities separately enumerated in the published returns for 1879 and on an additional 14 southern and western cities for which data first became available in 1889. The cities for which I

${ }^{12}$ Until 1905, the Census Bureau defined the census year for manufacturing data to be the 12 months ending on May 31 of the census year, but firms were allowed to submit reports for the business year coinciding most closely with the census year. In most cases, the reported data seem to pertain to the preceding calendar year. Beginning with the 1905 census, the census year was shifted to coincide with the previous calendar year to reflect this practice, and greater efforts were made to ensure that all firms reported statistics for this period (Easterlin, "Estimates," pp. 679-80).

${ }^{13}$ In 1914 and 1919 employment is reported separately by age and sex for December. I have assumed that the proportions of men, women, and children in the labor force remained constant throughout the year, to obtain average employment figures for these two censuses.

${ }^{14}$ By definition total earnings for all workers in city $i$ can be written as

$$
E_{i}=W M_{i}{ }^{*} L^{m}{ }_{i}+W F_{i}{ }^{*} L_{i}^{f}+W C_{i}{ }^{*} L^{c}{ }_{i}
$$

where $W M, W F$, and $W C$ are average earnings of men, women and children, respectively, and $L^{m}, L^{f}$, and $L^{c}$ are the average employment of men, women, and children respectively. Defining $F_{i}=W F_{i} / W M_{i}$ and $C_{i}=W C_{i} / W M_{i}$, and rearranging terms, the average earnings of adult men can be written as

$$
W M_{i}=E_{i} /\left\{L^{m}{ }_{i}+F_{i}{ }^{*} L_{i}^{f}+C_{i}{ }^{*} L_{i}^{c}\right\}
$$

$F, C$, and $W M$ can be calculated directly in 1889, 1899 and 1904; but in other years the average earnings of men can be imputed by substituting reasonable estimates of $F$ and $C$ for each city based on the data for 1889-1904. According to Goldin, Understanding, it does not appear unreasonable to assume a constant male-female earnings ratio over the period under consideration: "Nationwide the ratio of female to male earnings in manufacturing rose slowly from 1850 to 1885 , when it reached a value of about 0.56 . ... Although the ratio has varied considerably with economic fluctuations over the last century, ... over the long run it has not materially budged from its value in 1885" (pp. 63-66). Comparison of the ratios of women's and children's earnings to those of adult males in the years for which these data are available reveals substantial intercity variation. But consistent with Goldin's national estimates, these earnings ratios remained fairly steady over time within each city. I imputed male earnings in each city using the values of $F$ and $C$ for that city from the 1889, 1899, and 1904 censuses. Because of the changes in census coverage that occurred after 1899 (to be discussed later in this section), I used the 1904 earnings ratios to impute male earnings in 1909, 1914, and 1919 and the averages of the earnings ratios in 1889 and 1899 to impute male earnings in 1879 . 
have collected data are listed in the Appendix by census division. ${ }^{15}$ Because of changes in city boundaries that resulted in the incorporation of Brooklyn into New York City and Allegheny into Pittsburgh, the number of observations drops to 112 in 1904. In addition, data on the age and sex composition of the labor force were not available for Washington, DC, in 1914 or 1919, reducing the number of observations to 111 in those years.

Between 1879 and 1919 two important changes took place in census methods and coverage, but their impact on the comparability of the average earnings figures over time appears quite limited. The first was a revision in the methods used to measure average employment. For 1879 and 1889 instructions to enumerators indicate that employers were asked to report a single number reflecting average employment during that part of the year when the plant was in operation. If workers seasonally unemployed at one establishment were successful in finding alternative employment during times of slack demand, this procedure would result in double counting in the employment figures, thus biasing upward average employment and biasing downward the resulting earnings estimate. It is also possible that seasonally unemployed workers found employment in other sectors. To the extent that this occurred, average manufacturing earnings would further understate average annual income.

Beginning with 1899, separate employment figures were requested for each month, and the census bureau computed average employment by summing these figures and dividing by $12 .{ }^{16}$ In effect, census employment estimates for 1899 and later years reflect the number of full-time workers that would have been needed were production spread evenly throughout the year. To the extent that employment was seasonal or plants shut down for one or more months due to slack demand, this procedure would bias average employment downward relative to employment when the plant was in operation, and hence bias upward the estimated level of earnings. In these years average earnings are best interpreted as the amount that a full-time worker would earn if employed all year. In effect they are a measure of the daily (hourly) wage rate multiplied by the number of days (hours) worked per year by a year-round employee. As such, they are conceptually quite similar to the occupational wage data that have been used in previous research.

\footnotetext{
${ }^{15}$ For the most part, I have followed the standard census definitions in assigning the cities to regions; but on the basis of location and other characteristics, I have included four cities along the southern shore of the Ohio River-Covington, KY, Louisville, KY, Newport, KY, and Wheeling, WVA-in the East North Central region, rather than the South Central; and I have included Wilmington, DE, in the Middle Atlantic, rather than the South Atlantic.

${ }^{16}$ For 1899 and 1904 employers were asked to report average employment for each month. Beginning with 1909, they were asked to report the employment on the 15th of each month, or the nearest representative day for which they were in operation. This latter sampling approach probably provides a more accurate measure of employment at a particular establishment, but so long as individual employers did not err systematically in estimating average employment, it should have no appreciable effect on the aggregate statistics.
} 
The practical consequences of this shift in employment concepts were quite small. Because employment fluctuations were highly correlated across industries and did not mesh closely with seasonal fluctuations in agricultural labor demand, opportunities for reemployment-and hence the extent of downward bias in earnings in 1879 and 1889-were quite limited. ${ }^{17}$ Some insight into the impact of the change in employment concepts can be gained by comparing the ratio of manufacturing employment to population in each city in 1889 and 1899. To the extent that the change in census employment concepts affected measured employment, there should be a systematic shift in these employment to population ratios between the two dates. Reflecting the varying importance of manufacturing across cities, there were substantial differences in employment to population ratios across locations, but within most cities the change in census employment concept had a limited impact. For men, the average change in the employment to population ratio from 1889 to 1899 was -0.016 with a variance of 0.003 ; for women the average change was 0.0001 , with a variance of $0.0005 .{ }^{18}$ Thus, although there was essentially no change for women, it appears that a small amount of double counting of male workers did occur prior to 1899 . Given the small variance of the changes in individual cities around the average, however, this double counting should not pose a major problem for studying geographic variations in earnings over time. ${ }^{19}$

The second potential discontinuity in the census data is the result of shifts in the scope of census coverage. There were minor changes in coverage at each census, and a major redefinition occurred in 1904, when handicraft and neighborhood industries were excluded from the enumeration. The most significant impact of this change was to remove most of the building trades and a number of branches of clothing manufacture from the census. ${ }^{20}$ Elimination of hand and custom work reduced overall

\footnotetext{
${ }^{17}$ Comprehensive data on seasonal employment patterns were first collected as part of the 1900 census. Based on these data, Engerman and Goldin, "Seasonality," pp. 111-16, found that although manufacturing employment fluctuated substantially over the course of the year, these fluctuations were highly correlated across industries. They also found that patterns of employment variation were quite similar across regions, suggesting that even if average earnings estimates for 1879 and 1889 were reduced to some extent by double counting in the employment figures, this bias is not likely to have had much impact on relative regional earnings levels. Within each region, they compared the timing of agricultural demand fluctuations with those in manufacturing and concluded that "there is some reason to doubt that industrial laborers found substantial employment opportunities in agriculture during the trough periods in industry."

${ }^{18}$ The aggregate employment to population ratio might also be expected to fluctuate from year to year in response to economic fluctuations. Fortuitously, the two census years considered here both coincided with the initial phases of economic expansions, so the economic conditions would appear to be roughly similar (Easterlin, "Estimates," p. 679).

${ }^{19}$ This conclusion is reinforced by the fact that the change in census employment concepts between 1889 and 1899 has almost no effect on relative average earnings by region, as will be seen from inspection of Table 1 , to be discussed later.

${ }^{20}$ Until 1904 the census included the following building trades industries under the category of manufacturing: carpentering; brick and stone masonry; plumbing; house, sign and other painting;
} 
employment and payrolls by about 20 percent and the number of establishments by nearly half. These changes in coverage make it more difficult to use the census to identify long-run trends in the levels of earnings and other variables, but they affect intercity and interregional differentials at a point in time only to the extent that changes in coverage varied across locations.

Fortunately, it is possible to assess this impact directly, because at the 1905 census the Census Bureau recalculated the returns from 1899 to make the coverage comparable with that adopted for 1904. Comparing the two sets of figures for 1899 reveals that although both employment and payrolls fell about 20 percent, average annual earnings were reduced by just 2 percent as a result of the exclusion of hand and neighborhood trades. Moreover, the effect on earnings was quite uniform across cities and regions. $^{21}$

\section{GEOGRAPHIC VARIATION IN CENSUS EARNINGS}

Census average earnings and occupational wages provide two largely independent sources of information on late nineteenth-century labor markets. Where it is possible to compare directly earnings and wages across cities, however, they reveal very similar patterns of variation. For the 12 cities represented in the Bulletin 18 data, the correlation coefficient between nominal average earnings and an index of occupational wages increased from 0.65 in 1879 to 0.77 in 1889 , and reached 0.82 in $1899 .{ }^{22}$ There is no reason to expect that manufacturing earnings will vary in precisely the same way as daily wages for a small sample of mostly skilled occupations, but what is striking is the existence of a strong positive association between earnings and wages, and one that appears to grow stronger over time. The pattern of earnings variation in 1889 can also be compared to average wages for three separate occupation groups-skilled construction, skilled metalworking, and unskilled labor-in as many as 40 cities in 1890 reported in the Nineteenth Annual Report. The correlation coefficient between earnings and wages ranged from 0.75 for the skilled

paperhanging; plastering and stuccowork; roofing; and paving. In 1899 these industries accounted for close to 10 percent of all manufacturing employment. The changes in census coverage over time and the adjustments necessary to produce a consistent time series of aggregate manufacturing activity are discussed in more detail in Easterlin, "Estimates," pp. 641-52.

${ }^{21}$ The standard deviation of the difference in earnings resulting from the change in census coverage was just 3 percent of average earnings. Looking at the effects by region also reveals no systematic geographic differences. The average ratio of earnings excluding hand and neighborhood trades to average earnings including these industries was 0.98 or 0.99 in each region.

${ }^{22}$ The index of relative occupational wages measures systematic differences in wages across cities, using the city effect from a regression of log wages on dummy variables for each city and occupation. Rosenbloom, "One Market?" reported indices for five-year periods, so earnings at each census are compared to wages in the period ending in the census year. In these comparisons neither earnings nor wages are adjusted for cost of living differences, because any adjustment would affect them in the same way, thus leading to a potentially spurious correlation. 
TABLE 1

AVERAGE ANNUAL EARNINGS OF MALE WAGE EARNERS IN MANUFACTURING ADJUSTED FOR INTERCITY COST OF LIVING DIFFERENCES, 1879-1919

\begin{tabular}{lrrrrrrrr}
\hline Region & 1879 & $1889-\mathrm{A}$ & $1889-\mathrm{B}$ & 1899 & 1904 & 1909 & 1914 & 1919 \\
\hline \multicolumn{7}{c}{ Average Earnings (current dollars) } \\
MA & 426.37 & 528.33 & 528.33 & 511.59 & 534.83 & 607.68 & 671.24 & $1,297.23$ \\
NE & 422.04 & 510.63 & 510.63 & 504.73 & 519.47 & 585.65 & 633.98 & $1,197.82$ \\
ENC & 445.60 & 528.61 & 528.61 & 521.41 & 576.66 & 612.47 & 710.00 & $1,268.82$ \\
WNC & 536.07 & 581.23 & 568.34 & 545.41 & 594.51 & 649.87 & 722.36 & $1,257.94$ \\
SA & 355.54 & 432.20 & 420.16 & 374.73 & 414.26 & 458.78 & 493.33 & $1,005.72$ \\
SC & 456.36 & 509.89 & 511.53 & 470.77 & 492.62 & 529.02 & 574.81 & $1,027.28$ \\
West & 498.92 & 623.20 & 639.16 & 553.43 & 674.98 & 757.57 & 834.38 & $1,470.30$ \\
& 1007.07 & & \\
MA & 100.00 & 100.00 & 100.00 & 100.00 & 100.00 & 100.00 & 100.00 & 100.00 \\
NE & 98.98 & 96.65 & 96.65 & 98.66 & 97.13 & 96.37 & 94.45 & 92.34 \\
ENC & 104.51 & 100.05 & 100.05 & 101.92 & 107.82 & 100.79 & 105.77 & 97.81 \\
WNC & 125.73 & 110.01 & 107.57 & 106.61 & 111.16 & 106.94 & 107.62 & 96.97 \\
SA & 83.39 & 81.80 & 79.53 & 73.25 & 77.46 & 75.50 & 73.50 & 77.53 \\
SC & 107.03 & 96.51 & 96.82 & 92.02 & 92.11 & 87.05 & 85.63 & 79.19 \\
West & 117.02 & 117.96 & 120.98 & 108.18 & 126.20 & 124.67 & 124.30 & 113.34 \\
\hline
\end{tabular}

Notes: Regional Abbreviations: MA-Mid-Atlantic; NE-New England; ENC—East North Centràl; WNC-West North Central; SA-South Atlantic; SC-South Central; West-West. For cities in each region, see Appendix Table 1. For 1889 two figures are reported; the column labeled 1889-A is based on the same 100 cities used for 1879 , whereas the column labeled 1889-B shows average earnings for all 114 cities in the sample. Earnings are adjusted in each year for intercity differences in the cost of living, but not for changes over time in the general price level. Details of the cost of living adjustment are provided in the text.

Sources: U.S. Department of the Interior, Census Office, Twelfth Census, Manufactures; U.S. Department of Commerce and Labor, Bureau of the Census, Manufactures, 1905; Thirteenth Census, Manufactures; Census of Manufactures, 1914; Fourteenth Census, Manufactures; and Haines, "State and Local Consumer Price Index."

building trades to 0.66 for unskilled labor, and 0.44 for skilled metalworkers. $^{23}$

Table 1 presents unweighted regional averages of real census earnings of male manufacturing wage earners. To obtain real earnings, I deflated nominal earnings by state cost of living indices based on Michael Haines's analysis of 1890 retail price data from the Aldrich report. ${ }^{24}$ There are no data to construct location-specific cost of living estimates between 1870 and 1890, so I used Haines's index for 1890 to deflate earnings in both 1879 and 1889. For subsequent years, I adjusted his indices for differences in

${ }^{23}$ Average wages are from Rosenbloom, "Occupational Differences." The extent of correlation between earnings and wages implied by these regressions is comparable to that between relative wage levels for the different occupational groups. For example, the correlation between the wages of skilled building workers and unskilled laborers is 0.65 . The relatively weak relationship between earnings and skilled metalworkers' wages appears attributable largely to the fact that although wage rates in six cities located in the South Central region were quite high, earnings in these cities were low.

${ }^{24}$ Michael Haines, "State and Local Consumer Price Index." Haines also reported cost of living estimates for 70 individual cities. I use the state-level index, however, because it is possible to match only a fraction of the cities for which earnings data are available to cities for which cost of living estimates are provided. 
regional price trends on the basis of data reported by the U.S. Department of Labor. ${ }^{25}$ Haines's index includes commodities representing approximately 86 percent of consumer expenditures. The only major category of expenditures excluded is housing. It is unfortunate that data on housing costs, which are likely to have been one of the most variable components of expenditures, are too rare to be included, but their small weight in total expenditures means that even if they varied substantially they would not have a great effect on the overall index. ${ }^{26}$

It is apparent from Table 1 that real earnings were essentially equalized across the New England, Middle Atlantic, and East North Central regions as early as 1879 , and remained quite close thereafter. Although more sizeable differentials emerged occasionally, such as the rise in relative earnings in the East North Central in 1904, they were quickly eliminated. Earnings in the West North Central region began in 1879 well above eastern levels but converged very quickly during the 1880s, so that by 1889 the differential with the Middle Atlantic region had fallen to only about 8 percent, where it remained until 1919. In the 20 years from 1879 to 1899 , earnings in the West were converging toward eastern levels, but this trend was reversed around the turn of the century, with the gap jumping back into the 20 to 25 percent range until at least 1914. Earnings in the two southern regions were converging with each other at the same time that they were falling increasingly below northern levels. In the South Atlantic region, earnings were already 16 percent below the Middle Atlantic in 1879 and fell sharply over the next two decades, increasing the NorthSouth gap by nearly 50 percent. Although earnings in the South Central region were initially relatively high, they fell consistently over the next four decades, reaching equality with the South Atlantic in 1919. ${ }^{27}$

Interregional differentials are only one dimension of earnings variations. Within each region, earnings varied around their average level; but within

\footnotetext{
${ }^{25}$ U.S. Department of Labor, "Retail Prices, 1890," "Retail Prices, 1907," and "Retail Prices, 1913."

${ }^{26}$ Haines, "State and Local Consumer Price Index," did report an index of the rental cost per room for 21 states based on data drawn from an 1889/90 survey of consumer expenditures conducted by the U.S. Commissioner of Labor. This index exhibits much greater variability than other components of expenditures, ranging from a low of $58.2(100=$ average across all states $)$ in Connecticut to a high of 130.8 in Indiana. Despite these variations, however, inclusion of housing costs has only a small effect on the overall index of living costs. In 10 of 21 states the difference between the cost of living with and without housing costs is less than 2 percentage points, whereas in only 3 is it greater than 5 percentage points. Taking an unweighted average of Haines's rental cost index for the states in each region, housing costs were lowest in the New England (81.5), Middle Atlantic (86.3), and South Atlantic (85.3) regions, and highest in the North Central (119.1) and South Central (117.1) regions. Thus it would appear that the effect of excluding housing costs from the cost of living index is to overstate the average earnings figures in the North and South Central regions relative to the Northeast and South Atlantic. Incorporating housing costs would therefore not radically alter the results reported in Table 1 . The relatively higher cost of living in the North and South Central regions would (1) narrow the already small West-East earnings gap in the North, (2) increase the equalization of wages across the two southern regions, and (3) increase the North-South gap.

${ }^{27}$ Gavin Wright, "Postbellum Southern Labor Markets," documented a similar pattern of withinregion convergence and between-region divergence in farm wages at this time.
} 
TABLE 2

WITHIN REGION COEFFICIENT OF VARIATION OF AVERAGE EARNINGS OF MALE MANUFACTURING WAGE EARNERS, 1879-1919

\begin{tabular}{llllllll}
\hline \hline Region & 1879 & 1889 & 1899 & 1904 & 1909 & 1914 & 1919 \\
\hline MA & 0.124 & 0.133 & 0.086 & 0.081 & 0.077 & 0.073 & 0.086 \\
NE & 0.149 & 0.117 & 0.104 & 0.116 & 0.114 & 0.112 & 0.092 \\
ENC & 0.068 & 0.094 & 0.064 & 0.089 & 0.079 & 0.104 & 0.108 \\
WNC & 0.118 & 0.117 & 0.100 & 0.086 & 0.085 & 0.101 & 0.077 \\
SA & 0.304 & 0.204 & 0.236 & 0.196 & 0.197 & 0.125 & 0.148 \\
SC & 0.325 & 0.173 & 0.147 & 0.158 & 0.108 & 0.097 & 0.086 \\
West & 0.058 & 0.072 & 0.092 & 0.047 & 0.078 & 0.054 & 0.090 \\
\hline
\end{tabular}

Notes: Regional abbreviations are the same as those used in Table 1. The coefficient of variation is calculated as the ratio of the standard deviation of earnings to the average level of earnings across all cities for which data are available in each region at each date.

Sources: See the sources for Table 1.

the North, this variation was relatively small, and in most cases the extent of variation was falling over time. Table 2 reports one measure of this within-region variation: the coefficient of variation of earnings. The greatest dispersion in earnings occurred within the two southern regions, where the coefficient of variation was greater than 0.3 in 1879 , approximately three times as large as the dispersion in the other regions of the country. In both regions, however, earnings converged dramatically, so that by the end of the period, dispersion was comparable to that in other parts of the country. Similar, though weaker trends toward regional equalization are also apparent within New England, the Middle Atlantic, and West North Central regions. In the East North Central and West regions, where there was no trend in earnings dispersion, the extent of within-region variation was already quite low in 1879 .

Several features of the earnings data are worthy of note. The first is the near equalization of earnings across the Northeast and East North Central regions throughout the entire period covered by the data, and the rapid convergence of earnings in the West North Central region toward eastern levels from 1879 to 1889 . Earnings were not, of course, completely equalized, but in comparison to both the within-region dispersion of earnings in the South and the magnitude of the North-South differential in earnings, intra- and interregional variations in northern earnings appear small. The difference in earnings between the North Central and Northeast is also well below that found in more recent data. In the 1970s and 1980s, for example, real manufacturing wages in the Midwest were roughly 12 to 17 percent higher than in the Northeast, a differential about 2 to 3 times as large as the earnings data imply existed in the late nineteenth century. ${ }^{28}$

The equalization of northern earnings in the late nineteenth century is consistent with the equalization of occupational wage differentials in 1890

\footnotetext{
${ }^{28}$ Montgomery, "Evidence," calculated regional wage gaps, controlling for human capital differences, using data from the Current Population Survey.
} 
implied by the Aldrich Report and the Nineteenth Annual Report. On the other hand, the earnings data appear to conflict with my earlier analysis of the Bulletin 18 wage data, which found large and persistent interregional real wage differentials from 1870 to $1898 .{ }^{29}$ The earnings data are not, however, entirely at odds with the Bulletin 18 wage data. Indeed, as was noted earlier, the patterns of nominal wage and earnings variation across the 12 cities covered by the Bulletin 18 data are quite similar. In part, the difference in interregional differentials implied by the earnings examined here and my earlier analysis of the Bulletin 18 wage data is a consequence of the use of different cost of living deflators. Both Haines's state-level cost of living indices, which are used to deflate the earnings data in Table 1, and the city-specific cost of living indices that I used in my earlier analysis of the wage data imply that prices were lower in the North Central region than in the Northeast, but the size of the interregional differential is smaller in the state-level indices. ${ }^{30}$ For the nine Northeast and North Central cities covered by Bulletin 18, Haines has also calculated cityspecific cost of living indices for 1890 based on a broader array of commodities than the cost of living indices that I constructed in my earlier analysis. Haines's city-specific estimates suggest that although his statelevel cost of living deflators understate the extent of the interregional price differentials for these nine cities, my earlier estimates, which were based only on retail food prices, overstate the interregional differential. The effects of using Haines's city-specific cost of living estimates to deflate both earnings and wages are examined in Table 3. Using the same cost of living deflator reduces the magnitude of the interregional real wage gap and increases the size of earnings differentials between the four North Central and five Northeast cities covered by Bulletin 18. Consequently, the earnings and wage data are in substantial agreement about the size of differentials in the late 1870 s, but they present a very different picture of how these differentials evolved: although earnings converged, the Bulletin 18 wages did not. ${ }^{31}$

The second feature of the earnings data is the large and growing gap between northern and southern earnings. Although there is little inform ation about southern wage trends, relative earnings in the South Atlantic

\footnotetext{
${ }^{29}$ The Weeks data also suggest the presence of large interregional differentials as late as 1880 , but it is difficult to compare directly these wage differentials to the earnings data, because Coelho and Shepherd, "Regional Differences," did not report earnings for individual cities.

${ }^{30}$ The correlation coefficient between the two indexes for the nine eastern and midwestern cities covered by the Bulletin 18 data is 0.80 .

${ }^{31}$ In view of the independent evidence of interregional real wage convergence provided by the Aldrich Report and Nineteenth Annual Report data, it seems likely that the absence of convergence in the Bulletin 18 wages is an artifact of the small and potential unrepresentative sample on which they are based. As noted earlier, the Bulletin 18 data were drawn from a sample of employers who had been in operation continuously throughout the period from 1870 to 1898 , and it seems conceivable that although wages paid by these employers at the beginning of this period reflected more general 1 a bor market conditions at that time, they may not have fully reflected subsequent developments in the labor market.
} 
TABLE 3

THE EFFECT OF DIFFERENT COST OF LIVING INDICES ON INTERREGIONAL REAL WAGE AND EARNINGS DIFFERENTIALS, 1879-1899

\begin{tabular}{|c|c|c|c|c|}
\hline \multirow[b]{3}{*}{ Date } & \multicolumn{4}{|c|}{$\begin{array}{l}\text { Relative North Central Earnings or Wages } \\
\qquad(\text { Northeast }=100)\end{array}$} \\
\hline & \multicolumn{2}{|c|}{$\begin{array}{c}\text { Occupational Wages } \\
\text { Deflated by }\end{array}$} & \multicolumn{2}{|c|}{$\begin{array}{c}\text { Census Average Earnings } \\
\text { Deflated by }\end{array}$} \\
\hline & $\begin{array}{c}\text { Rosenbloom } \\
\text { City COL Index } \\
(1)\end{array}$ & $\begin{array}{l}\text { Haines City } \\
\text { COL Index } \\
(2)\end{array}$ & $\begin{array}{c}\text { Haines State } \\
\text { COL Index } \\
\text { (3) }\end{array}$ & $\begin{array}{c}\text { Haines City } \\
\text { COL Index } \\
(4)\end{array}$ \\
\hline 1879 & 128.0 & 116.0 & 109.2 & 114.2 \\
\hline 1889 & 121.8 & 113.1 & 99.8 & 104.5 \\
\hline 1899 & 120.5 & 112.4 & 98.1 & 99.9 \\
\hline
\end{tabular}

Notes and Sources: Each column reports the ratio of real wages or earnings in four North Central cities-Cincinnati, Chicago, St. Louis, and St. Paul-to real wages or earnings in five Northeast cities-New York, Boston, Baltimore, Philadelphia, and Pittsburgh. Earnings in 1879 and 1889 are compared to relative wages calculated for the five-year period ending in the census year. Earnings in 1899 are compared to relative wages calculated for 1895 to 1898 . The wage ratio in the first column is reported in Rosenbloom, "One Market?" table 2. The wage ratio in the second column was calculated by deflating relative nominal wage rates in each city reported in Rosenbloom, "One Market?" table 1, using the city-specific cost of living index reported by Haines, "State and Local Consumer Price Index," and then averaging real wages across the cities in each region. The earnings ratios in the third and fourth columns were computed by deflating average annual earnings from the census by Haines's state-level and city-specific cost of living indices, respectively, and then averaging real earnings across the cities in each region.

and South Central regions in 1889 are consistent with the evidence on the level of real wages found in studies using the Aldrich Report and Nineteenth Annual Report data. ${ }^{32}$ The earnings data extend knowledge to a broader geographical sample and allow us to follow the evolution of North-South differences over a longer period. The time series nature of the earnings data is especially helpful, in the case of the South Central region, where wages and earnings were roughly equal to northern levels until about 1890 . However, the earnings data clearly indicate a long-run decline within this region that is only hinted at in the wage data.

The long-run decline of earnings in the South Central region gives rise to the third notable feature of the data, the strong tendency toward wage convergence within the South. In 1879 the earnings differential between the South Atlantic and South Central regions was larger than that between the South Atlantic and Middle Atlantic regions. By 1919, however, earnings in the South Atlantic and South Central regions were nearly equal. Paralleling this interregional convergence was an equally pro-

${ }^{32}$ The only evidence on the trend in relative wages in the South is from Bulletin 18, which provides wage quotations for Richmond (in the South Atlantic) and New Orleans (in the South Central). Rosenbloom, "One Market?" found that real wages in Richmond fell from 86 percent of New York wages between 1870 and 1874 to 81 percent between 1895 and 1898. Real wages in New Orleans displayed no trend over this period, remaining approximately equal to wages in New York. 
nounced decline in the within-region dispersion of earnings in the two southern regions.

\section{EARNINGS VARIATION AND LABOR MARKET INTEGRATION}

The pattern of earnings variation revealed by Tables 1 and 2 suggests the existence of at least two distinct regional labor markets within the United States from 1879 to 1919 -one northern and one southern. At this point, it is not entirely clear from the behavior of western earnings-converging toward eastern levels until 1899 and then diverging again-whether western cities were part of the northern labor market or constituted a third distinct regional market of their own. Tables 1 and 2 do not, however, take account of the effects on earnings of labor force heterogeneity, locational characteristics, or temporary supply or demand shocks. Before the earnings data can be used to draw inferences about labor market integration it is necessary to take into account how these other factors may have affected earnings.

The problem of using earnings variations to draw inferences about the extent of market integration can be formalized by writing earnings, $E$, in location $i$ at time $t$ as

$$
E_{i t}=G\left(S_{i t}, Y_{i t}, P_{i t}, Q_{i t}, V_{i t}\right)
$$

where $S$ is a vector of variables measuring nontraded locational attributes, $Y$ is a vector of labor force characteristics, $P$ is the local price level, $Q$ is a measure of temporary disequilibrating shocks, and $V$ is a measure of permanent differences in local supply and demand conditions. ${ }^{33}$ Equation 1 is a reduced form describing the equilibrium variation in earnings across location and has no structural interpretation. Empirical application of equation 1 requires that the function $G(\quad)$ be approximated by some specific functional form. If we adopt a log-log specification, equation 1 becomes

$$
e_{i t}=a+b s_{i}+c y_{i t}+d p_{i t}+f q_{i t}+v_{i t}
$$

where lower case variables indicate natural logarithms, and $a, b, c, d$, and $f$ are vectors of coefficients to be estimated. This expression can be estimated by ordinary least squares regression of log earnings on measures of locational characteristics, labor force composition, temporary shocks,

\footnotetext{
${ }^{33}$ Roback, "Wages," made the point that general equilibrium requires the equalization of both utility and the returns to capital across locations. Together, these conditions uniquely determine both nominal earnings and the local price level as functions solely of the nontraded characteristics of each location. The importance of considering both equilibrium conditions simultaneously depends on the importance of local variation in prices on the returns to capital. If, as seems likely in the late nineteenth-century context, local variation in prices was dwarfed by other considerations such as access to raw materials, low-cost transportation, proximity to expanding markets (and the availability of an adequate labor supply), then the capital market equilibrium condition can be safely dropped from consideration. In this case the worker equilibrium condition is well identified, and the cost of living can be treated as an exogenous variable, as is done here.
} 
and the local cost of living. Provided that the other determinants of earnings are adequately measured, the residual variation in earnings $\left(v_{i t}\right)$ can be interpreted as a measure of the impact of persistent differences in local labor market conditions on earnings. Although I am unable to control adequately for all of the potential effects of labor heterogeneity, locational characteristics, and temporary disequilibrating shocks that may have influenced earnings, to the extent that I can control for these factors, they reinforce the patterns found in Tables 1 and 2; thus it seems unlikely that a more complete accounting would alter the pattern of inter- and intraregional differentials significantly.

The need to control for labor heterogeneity arises because census earnings data are an average across all adult male wage earners in each city. Aggregate census occupational statistics show that by the turn of the century, two-thirds of male blue-collar workers were either operatives or laborers, whereas only one-third were craftsmen, foremen, or other more skilled workers. ${ }^{34}$ Differences in these proportions across cities are likely to be one important source of earnings variation. In the subsequent analysis, I control for this source of variation by including the fraction of male manufacturing workers in two of the numerically most important groups of skilled craft occupations-construction and metalworking-as well as the fraction of the adult male labor force giving their occupation simply as laborers. ${ }^{35}$ Although construction is not properly part of manufacturing, it was included in the manufacturing census until 1904, so it is important to control for the presence of highly paid building workers.

It is more difficult to measure variations in human capital across the mass of production workers. There is widespread agreement among labor and economic historians that increasing scale and the standardization of products in U.S. manufacturing during the late nineteenth century promoted the increasing homogenization of the factory labor force. According to Claudia Goldin, "most manufacturing jobs were easily learned," and "with the exception of jobs like supervisor [and high-skilled occupations like steel puddlers], most could be handled by the average entrant." 36 Despite the increasing homogenization of the mass of manufacturing workers, however, they cannot be treated as an entirely undifferentiated body of labor. Although technological changes were contributing to the reduction of traditional craft-based skills, they were also creating the need for new kinds of skills learned primarily on the job. ${ }^{37}$ To control as best I

${ }^{34}$ U.S. Department of Commerce, Historical Statistics, p. 74.

${ }^{35}$ Unfortunately, the occupational statistics for this period do not provide much guidance about the sectoral affiliation of laborers. Thus it is necessary to use the proportion of laborers in the total labor force.

${ }^{36}$ Goldin, Understanding, p. 115, and "Labor Markets," pp. 24-25. Similarly, Gordon, Edwards, and Reich, Segmented Work, p. 118, contended that "more and more wage earners in manufacturing shared the experience of working in similar kinds of jobs.... Now, more and more, there was a single class of semiskilled factory operatives." See also, Nelson, Managers, pp. 79-100.

${ }^{37}$ The growing importance of on-the-job training was not at this time manifested in formal 
can for these sorts of differences, I include both the fraction of the adult male population that was literate in each city and measures of the age distribution of the adult male population, which may serve as a rough proxy for years of experience.

Historical research on urban amenities has concentrated on the effects of mortality-interpreted both as a disamenity in its own right and as an index of other undesirable characteristics like inadequate sanitation, and overcrowding. ${ }^{38}$ Other available measures of amenities that have been commonly used include city size and climatic conditions. ${ }^{39}$ Larger cities may be associated with crowding, which diminishes the quality of life, or a greater diversity of goods and services, which presumably increases the quality of life. Larger cities are likely to have more diverse employment opportunities as well, which may allow for better matching of workers' skills and employers' requirements. Better weather conditions presumably increase residents' enjoyment of a location.

Variations in the length of the workweek and differences in the risk of unemployment across cities could in principal have affected the relative attractiveness of different locations as well. ${ }^{40}$ In practice, however, neither of these factors appears especially important, and I do not control for them in the subsequent analysis. Other things equal, workers would presumably prefer to work fewer hours for any given level of real earnings, but recent research has not found pronounced geographic differences in daily or weekly hours of work during the late nineteenth century. ${ }^{41}$ In 1879 and 1889 , the use of annual earnings rather than daily or hourly wages includes a partial correction for the effects of unemployment risk, because average earnings will be lower where unemployment is higher. ${ }^{42}$ Because of the shift in census employment concepts, however, earnings in 1899 and later

bureaucratic systems of internal promotion; but Sundstrom, "Internal Labor Markets," has shown that many firms relied heavily on internal promotion to fill more skilled positions, a phenomenon that he interprets as evidence of the importance of firm-specific skills learned through on-the-job training. Similarly, other researchers have shown that many workers could expect eventually to find relatively lengthy jobs, consistent with the importance of firm-specific human capital. Carter and Savoca, "Labor Mobility"; James, "Job Tenure"; and Sundstrom, "Internal Labor Markets," made the case for the importance of long-term attachments and on-the-job learning. See, however, Jacoby and Sharma, "Employment Duration," for a dissenting interpretation of the job-tenure evidence.

${ }^{38}$ See, for example, Williamson, "Was the Industrial Revolution?"; and Brown, "The Condition of England."

${ }^{39}$ Clark, Kahn, and Ofek, "City size"; and Roback, "Wages."

${ }^{40}$ Hall, "Why Is the Unemployment Rate?," examined the role of local variation in unemployment rates in explaining geographic variation in wages in contemporary data.

${ }^{41}$ Based on a national sample from the manuscript returns of the 1880 census of manufactures, Atack and Bateman, "How Long was the Workday?" reported that the workday was shortest in the South (9 hours and 56 minutes) and longest in the Northeast (10 hours and 9 minutes). This is a difference of just 2 percent. Using data on a sample of occupations from the Nineteenth Annual Report, Rosenbloom and Sundstrom, "Decline," found equally small variations in weekly hours around the turn of the century. Unless the marginal value of time was extremely high, this cannot explain very much of the observed North-South earnings gap.

${ }^{42}$ As noted earlier, in the section Census Earnings Data, average earnings data for these years will also understate actual earnings to the extent that seasonally unemployed manufacturing workers found 
years measure the potential income of a full-time, year-round employee. To the extent that unemployment risk was higher in some locations than in others, we would expect this to be compensated with higher pay. The available evidence does not, however, reveal any systematic relationship between earnings and unemployment. ${ }^{43}$

Assuming that labor market adjustment requires time, it is possible that earnings differences may reflect a temporary spatial disequilibrium rather than persistent differences in labor market conditions. It is not possible to directly measure labor supply and demand shocks in particular cities. Nonetheless, to the extent that earnings differences are due to such temporary shocks, they will necessarily be reflected in differences in subsequent migration rates. Data on migration to particular cities are not available, but differences in population growth rates should be closely correlated with differential rates of migration and can thus be used as a proxy for temporary spatial disequilibrium.

Before controlling for the effects of labor force heterogeneity, locational characteristics, and temporary shocks on earnings, it is necessary to establish a baseline for comparison. Table 4 presents estimates of equation 2 , in which the log of earnings is regressed on the log of the cost of living and a set of regional indicator variables taking the value one if the city is located in the region and zero otherwise. The regional effects are included to measure the extent of systematic variation in earnings across regions and will thus pick up systematic regional differences in demand conditions, amenities, or labor quality. Nonsystematic differences in amenities or labor force composition across cities, as well as local supply and demand shocks, are reflected in the error term of the regression. The constant term in the equation measures the level of earnings in the Middle Atlantic region, and the coefficients on the regional indicator variables measure the deviation of earnings in each corresponding region relative to the Middle Atlantic.

The coefficients for each region in Table 4 are analogous to the regional

employment outside of manufacturing. The actual size of such intersectoral flows appears to have been quite small, however.

${ }^{43}$ The 1900 population census was the first to collect comprehensive national data on unemployment in all forms of gainful employment. Fortunately, since the economy was close to full employment in 1900 , geographic variations in unemployment experience at this date are likely to reflect mainly the effects of differences in frictional and seasonal unemployment risks. Using data from the 1900 census Public Use Sample, Engerman and Goldin, "Seasonality," p. 118, showed that although unemployment risk among manufacturing workers varied little across the Northeast and North Central regions, the risk of unemployment was somewhat higher in the South and West. Higher unemployment risk may therefore explain some of the higher level of western earnings, but it cannot account for the low level of southern earnings. According to Engerman and Goldin, for manufacturing workers the probabilities of experiencing unemployment (in all gainful work), and the duration of unemployment conditional on becoming unemployed were as follows: Northeast-22.4 percent, 3.96 months; Midwest-21.7 percent, 3.85 months; South-22.5 percent, 4.24 months; and West -24.2 percent, 4.23 months. Multiplying the percentage experiencing unemployment by the expected duration conditional on becoming unemployed implies that the unconditional expected duration of unemployment was 0.887 months in the Northeast, 0.835 months in the Midwest, 0.954 months in the South, and 1.024 months in the West. 
TABLE 4

REGRESSION ESTIMATES OF REGIONAL EFFECTS ON AVERAGE EARNINGS OF MALE MANUFACTURING WORKERS, 1879-1919

\begin{tabular}{lcccccccc}
\hline \hline & 1879 & $1889-\mathrm{A}$ & $1889-\mathrm{B}$ & 1899 & 1904 & 1909 & 1914 & 1919 \\
\hline Constant & $6.042^{*}$ & $6.258^{*}$ & $6.261^{*}$ & $6.234^{*}$ & $6.283^{*}$ & $6.398^{*}$ & $6.487^{*}$ & $7.155^{*}$ \\
& $(0.031)$ & $(0.026)$ & $(0.025)$ & $(0.022)$ & $(0.023)$ & $(0.022)$ & $(0.020)$ & $(0.021)$ \\
NE & -0.030 & -0.039 & -0.031 & -0.013 & -0.024 & -0.029 & -0.036 & $-0.069^{*}$ \\
& $(0.051)$ & $(0.044)$ & $(0.041)$ & $(0.034)$ & $(0.036)$ & $(0.033)$ & $(0.030)$ & $(0.032)$ \\
ENC & 0.086 & 0.021 & 0.003 & 0.019 & 0.058 & 0.002 & $0.048^{* *}$ & -0.022 \\
& $(0.067)$ & $(0.057)$ & $(0.050)$ & $(0.046)$ & $(0.042)$ & $(0.031)$ & $(0.027)$ & $(0.030)$ \\
WNC & $0.278^{*}$ & 0.117 & 0.074 & 0.062 & 0.088 & 0.060 & $0.062^{* *}$ & -0.030 \\
& $(0.088)$ & $(0.075)$ & $(0.055)$ & $(0.051)$ & $(0.048)$ & $(0.037)$ & $(0.033)$ & $(0.036)$ \\
SA & $-0.219^{*}$ & $-0.215^{*}$ & $-0.240^{*}$ & $-0.330^{*}$ & $-0.267^{*}$ & $-0.272^{*}$ & $-0.240^{*}$ & $-0.219^{*}$ \\
& $(0.061)$ & $(0.052)$ & $(0.047)$ & $(0.042)$ & $(0.040)$ & $(0.044)$ & $(0.047)$ & $(0.058)$ \\
SC & 0.046 & -0.038 & -0.038 & $-0.089^{*}$ & $-0.081^{* *}$ & $-0.103^{* *}$ & -0.069 & $-0.192^{*}$ \\
& $(0.072)$ & $(0.062)$ & $(0.049)$ & $(0.042)$ & $(0.044)$ & $(0.056)$ & $(0.051)$ & $(0.058)$ \\
West & 0.099 & 0.144 & $0.200^{*}$ & 0.081 & $0.247^{*}$ & $0.252^{*}$ & $0.251^{*}$ & $0.119^{*}$ \\
& $(0.118)$ & $(0.100)$ & $(0.075)$ & $(0.058)$ & $(0.046)$ & $(0.051)$ & $(0.038)$ & $(0.039)$ \\
Log (cost of & $1.493^{* * * *} 1.213^{* * *}$ & $0.975^{* * *}$ & $0.983^{* * *}$ & $0.747^{* * *}$ & $0.632^{* * *}$ & 0.155 & $0.650^{* * * *}$ \\
living) & $(0.677)$ & $(0.576)$ & $(0.451)$ & $(0.400)$ & $(0.405)$ & $(0.394)$ & $(0.360)$ & $(0.385)$ \\
$R^{2}$ & 0.326 & 0.371 & 0.492 & .514 & 0.555 & 0.585 & 0.585 & 0.294 \\
$N$ & 100 & 100 & 114 & 114 & 112 & 112 & 111 & 11.1 \\
\hline
\end{tabular}

* = Significantly different from zero at 5 percent level.

** = Significantly different from zero at the 10 percent level.

*** $=$ Not statistically significantly different from one at the 5 percent level.

Notes: Regional abbreviations are the same as those used in Tables 1 and 2. Regional effects are estimated as the coefficients on zero-one indicator variables that take the value one when a city is in the region, and zero otherwise. The constant term measures the level of log average earnings in the Middle Atlantic region, and the regional effects measure the relative deviation of earnings in each region from this level. All regressions are estimated by ordinary least squares. The column headed 1889-A is estimated for the same 100 cities included in the estimates for 1879 , whereas the column headed 1889-B is estimated across all 114 cities in the sample. Standard errors are in parentheses.

Sources: U.S. Department of the Interior, Census Office, Twelfth Census, Manufactures; and Haines, "State and Local Consumer Price Index."

averages from Table 1, except that the average is calculated over log earnings and the coefficient of the cost of living is determined by the regression, rather than being assumed equal to unity. Reassuringly, the regional effects closely parallel the patterns of variation found in Table 1. The only difference of any note is that, although average earnings in the South Atlantic region appeared to drift downward relative to earnings in the Middle Atlantic and other parts of the North, Table 4 suggests a fluctuation in regional differentials with no clear trend. Although the coefficient on the cost of living is nowhere precisely equal to one, the hypothesis that its true value is one can be rejected only for 1914 . Paralleling the declining intraregional dispersion of earnings shown in Table 2, the increasing $R$-squared of the estimates over time indicates that systematic regional variations accounted for an increasing fraction of the total variation in earnings, whereas intraregional variations accounted for a smaller fraction of the total. The sharp drop in $R$-squared and the changes in some of the regional effects in 1919 suggest that World War I 
was associated with substantial shifts in labor supply and demand conditions to which the market had not completely adjusted by this date.

Table 5 examines the effects on the earnings regression of controlling for labor quality, local amenities, and temporary disequilibrium. Because of the stability of regional differences in earnings and the cost of collecting labor force and amenity data for other years, the analysis is restricted to a single year, 1899. The first column of the table repeats the results of the baseline regression for 1899 . Because data on locational characteristics and labor force composition are not available for all of the cities covered by the earnings data, column 2 repeats the baseline regression for the smaller sample of cities for which all of the explanatory variables are available. The pattern of regional variation is similar, but exclusion of several of the lowest-wage southern cities reduces the gap between earnings in the South Atlantic region and the North. At the same time, earnings in the East and West North Central regions are raised slightly, producing a greater degree of interregional variation within the North. The third through fifth columns add a variety of variables intended to control for variation in labor quality, locational characteristics, and temporary labor market shocks, respectively. The sixth column reports the results of including all three categories of explanatory variables simultaneously.

The regression in column 3 adds three variables intended to capture differences in occupational composition of the labor force-the fraction of male manufacturing workers employed in a variety of skilled building $(P C T B L D)$ and metalworking (PCTMETAL) occupations and the fraction of gainfully employed males giving their occupation as laborers $(P C T L A B)$-as well as the fraction of the population over 10 years of age that was illiterate and the fraction of the adult male population in four age categories: 15 to 24 years old, 25 to 34,35 to 44 , and 45 to $64 .{ }^{44}$ Controlling

${ }^{44}$ The building trades fraction reflects the sum of workers listing their occupations as carpenters and joiners, stone and brick masons, and plumbers and gas and steam fitters. The metal working trades fraction reflects the sum of workers listing their occupations as blacksmiths, iron and steel workers, steam boilermakers, and other metal workers. Regional variations in occupational composition were fairly substantial. Not surprisingly, building trades workers were most numerous in rapidly growing areas. In the West North Central, the West, and the two southern regions, 15 to 17 percent of males employed in manufacturing listed an occupation in the building trades, as compared to about 10 percent in the Middle Atlantic, East North Central, and New England regions. On the other hand, metal trades workers were most numerous in the Middle Atlantic, New England, and East North Central regions. Finally, laborers were somewhat more common in the South, accounting for nearly 16 percent of gainfully employed males, and least important in New England, where they were just 8 percent of the male labor force. In addition to the population characteristics included in the regression, data are also available on variation in the nativity and racial composition of the population across cities. Although these characteristics are often treated as proxies for skill, consideration of their relationship to earnings leads me to exclude them from the analysis. In particular, one would expect that if these dimensions of labor force variation were proxies for skill, their relationship to earnings should be fairly stable across different groups of cities. In fact, neither nativity nor race had a significant relationship with earnings outside the South. Within the South the fraction foreign-born was significantly and positively related to earnings levels, suggesting that differences in labor force 
for these aspects of labor quality improves the fit of the regression modestly, raising the adjusted $R$-squared from 0.35 to 0.39 . As expected, greater numbers of skilled construction and metal trades workers tended to raise average earnings. The coefficients on both these variables are positive and significant, statistically and economically. ${ }^{45}$ The coefficient on $P C T L A B$ indicates that greater numbers of the least-skilled workers tended to depress earnings, but the coefficient is not statistically significant. None of the age composition coefficients is statistically significant either, but their relative magnitudes are consistent with expectations, showing that greater numbers of the youngest and oldest age groups tended to depress earnings. Also consistent with expectations, the coefficient on the illiteracy rate is negative, though not statistically significant. Inclusion of these controls reduces the differential between the North Central regions and the Northeast relative to column 2, indicating that some of the intercity variation within these regions is indeed accounted for by differences in labor quality. To the extent that the North-South differential is affected, it is actually widened after controlling for labor quality.

Column 4 adds to the earnings regression the infant mortality rate measured in deaths per thousand (INFMORT), the logarithm of city population, and three variables intended to reflect different aspects of climatic conditions: (1) average annual sunshine as a percentage of potential sunshine $(S U N)$, (2) the log of the average temperature in January (JANTEMP), and (3) the annual precipitation in tenths of inches of rain $(R A I N)$. Inclusion of these explanatory variables increases the adjusted $R$-squared substantially, raising it to 0.48 . Most of the additional explanatory power comes from the city size variable, which indicates a strong and statistically significant positive relationship between earnings and population. One interpretation of this relationship is that increasing size was associated with disamenities such as crowding, which required compensating payments. Alternatively, city size may be a proxy for differences in housing costs, which are not directly reflected in the cost-of-living index. The coefficient on infant mortality is also statistically significant, but contrary to expectations, it is negative. Possibly this

composition were the result of differences in migration rates in response to earnings differences. In contrast, there was a strong negative relationship between earnings and the fraction nonwhite. Indeed, the elasticity of earnings with respect to the fraction nonwhite is close to -1 , suggesting that a 1 percent increase in the fraction nonwhite would lower earnings by 1 percentage point. Wright, Old South, pp. 68-70, argued, however, that there is little evidence of pronounced racial wage differentials within occupations in the South, suggesting that variations in the fraction nonwhite must be capturing some other factor affecting earnings.

${ }^{45}$ The coefficient estimates imply that a 1 percentage point increase in the share of skilled metal trades workers would increase average earnings by nearly 0.3 percent, whereas raising the share of skilled building trades workers 1 percent would increase earnings 0.83 percent. The smaller numbers of skilled metal workers in the South Atlantic thus can account for between 2 and 3 percent of the earnings disadvantage of that region, whereas-other things equal-the higher number of skilled building trades workers in the South Central region would have raised average earnings by nearly 6 percent relative to the Middle Atlantic. 
TABLE 5

REGRESSION ESTIMATES OF REGIONAL EFFECTS ON AVERAGE EARNINGS OF MALE MANUFACTURING WORKERS, CONTROLLING FOR DIFFERENCES IN OCCUPATION MIX AND LOCATIONAL CHARACTERISTICS, 1899

\begin{tabular}{|c|c|c|c|c|c|c|}
\hline Variable & (1) & (2) & $(3)$ & (4) & (5) & (6) \\
\hline Constant & $\begin{array}{c}6.234^{*} \\
(0.022)\end{array}$ & $\begin{array}{c}6.218^{*} \\
(0.022)\end{array}$ & $\begin{array}{r}6.636^{*} \\
(0.323)\end{array}$ & $\begin{array}{l}4.858^{*} \\
(0.639)\end{array}$ & $\begin{array}{r}6.202^{*} \\
(0.029)\end{array}$ & $\begin{array}{l}5.1423^{*} \\
(0.733)\end{array}$ \\
\hline New England & $\begin{array}{c}-0.013 \\
(0.034)\end{array}$ & $\begin{array}{c}-0.022 \\
(0.037)\end{array}$ & $\begin{array}{c}-0.023 \\
(0.041)\end{array}$ & $\begin{array}{c}-0.019 \\
(0.035)\end{array}$ & $\begin{array}{r}-0.014 \\
(0.038)\end{array}$ & $\begin{array}{c}-0.012 \\
(0.040)\end{array}$ \\
\hline $\begin{array}{l}\text { East North } \\
\text { Central }\end{array}$ & $\begin{array}{c}0.019 \\
(0.046)\end{array}$ & $\begin{array}{c}0.072 \\
(0.050)\end{array}$ & $\begin{array}{c}0.020 \\
(0.052)\end{array}$ & $\begin{array}{c}0.031 \\
(0.048)\end{array}$ & $\begin{array}{c}0.061 \\
(0.051)\end{array}$ & $\begin{array}{c}0.018 \\
(0.050)\end{array}$ \\
\hline $\begin{array}{l}\text { West North } \\
\text { Central }\end{array}$ & $\begin{array}{c}0.062 \\
(0.051)\end{array}$ & $\begin{array}{c}0.134^{*} \\
(0.057)\end{array}$ & $\begin{array}{c}0.062 \\
(0.068)\end{array}$ & $\begin{array}{l}0.085 \\
(0.057)\end{array}$ & $\begin{array}{c}0.124^{*} \\
(0.058)\end{array}$ & $\begin{array}{c}0.071 \\
(0.066)\end{array}$ \\
\hline South Atlantic & $\begin{array}{r}-0.330^{*} \\
(0.042)\end{array}$ & $\begin{array}{r}-0.189^{*} \\
(0.053)\end{array}$ & $\begin{array}{r}-0.196^{*} \\
(0.610)\end{array}$ & $\begin{array}{r}-0.252^{*} \\
(0.057)\end{array}$ & $\begin{array}{r}-0.185^{*} \\
(0.053)\end{array}$ & $\begin{array}{c}-0.253^{*} \\
(0.066)\end{array}$ \\
\hline South Central & $\begin{array}{r}-0.089 * \\
(0.042)\end{array}$ & $\begin{array}{c}-0.055 \\
(0.044)\end{array}$ & $\begin{array}{r}-0.086 \\
(0.055)\end{array}$ & $\begin{array}{c}-0.119 * * \\
(0.060)\end{array}$ & $\begin{array}{r}-0.061 \\
(0.044)\end{array}$ & $\begin{array}{c}-0.126^{* *} \\
(0.068)\end{array}$ \\
\hline West & $\begin{array}{c}0.081 \\
(0.058)\end{array}$ & $\begin{array}{c}-0.004 \\
(0.066)\end{array}$ & $\begin{array}{c}-0.012 \\
(0.073)\end{array}$ & $\begin{array}{c}-0.036 \\
(0.073)\end{array}$ & $\begin{array}{c}-0.020 \\
(0.068)\end{array}$ & $\begin{array}{c}-0.042 \\
(0.080)\end{array}$ \\
\hline $\log (\cos t$ of living $)$ & $\begin{array}{c}0.983 \\
(0.399)\end{array}$ & $\begin{array}{l}1.594^{* * *} \\
(0.441)\end{array}$ & $\begin{array}{l}1.172^{* * *} \\
(0.479)\end{array}$ & $\begin{array}{l}1.321 * * * \\
(0.423)\end{array}$ & $\begin{array}{l}1.465^{* * * *} \\
(0.459)\end{array}$ & $\begin{array}{l}1.243^{* * * *} \\
(0.460)\end{array}$ \\
\hline PCTLAB & & & $\begin{array}{c}-0.331 \\
(0.334)\end{array}$ & & & $\begin{array}{c}-0.274 \\
(0.317)\end{array}$ \\
\hline$P C T B L D G$ & & & $\begin{array}{l}0.834^{* *} \\
(0.452)\end{array}$ & & & $\begin{array}{l}0.782^{* *} \\
(0.451)\end{array}$ \\
\hline PCTMETAL & & & $\begin{array}{l}0.286^{* * *} \\
(0.158)\end{array}$ & & & $\begin{array}{c}0.339^{*} \\
(0.150)\end{array}$ \\
\hline$A G E \quad 15-24$ & & & $\begin{array}{c}-1.475 \\
(1.171)\end{array}$ & & & $\begin{array}{r}-1.274 \\
(1.083)\end{array}$ \\
\hline$A G E 25-34$ & & & $\begin{array}{c}0.273 \\
(0.933)\end{array}$ & & & $\begin{array}{c}0.160 \\
(0.919)\end{array}$ \\
\hline$A G E 35-44$ & & & $\begin{array}{c}-0.832 \\
(1.162)\end{array}$ & & & $\begin{array}{c}-1.209 \\
(1.119)\end{array}$ \\
\hline$A G E$ 45-64 & & & $\begin{array}{r}-0.849 \\
(0.777)\end{array}$ & & & $\begin{array}{c}0.565 \\
(0.822)\end{array}$ \\
\hline ILLITERATE & & & $\begin{array}{c}-0.413 \\
(0.335)\end{array}$ & & & $\begin{array}{c}0.389 \\
(0.476)\end{array}$ \\
\hline INFMORT & & & & $\begin{array}{r}-0.0005^{*} \\
(0.0002)\end{array}$ & & $\begin{array}{r}-0.0006^{*} \\
(0.0003)\end{array}$ \\
\hline LOG(population) & & & & $\begin{array}{r}0.042^{*} \\
(0.011)\end{array}$ & & $\begin{array}{r}0.052 * \\
(0.013)\end{array}$ \\
\hline$S U N$ & & & $\therefore$ & $\begin{array}{c}0.002 \\
(0.002)\end{array}$ & & $\begin{array}{c}0.002 \\
(0.002)\end{array}$ \\
\hline JANTEMP & & & & $\begin{array}{c}0.199 \\
(0.164)\end{array}$ & & $\begin{array}{c}0.171 \\
(0.176)\end{array}$ \\
\hline RAIN & & & & $\begin{array}{c}0.0002 \\
(0.0002)\end{array}$ & & $\begin{array}{c}0.0001 \\
(0.0002)\end{array}$ \\
\hline SHOCK & & & & & $\begin{array}{c}0.067 \\
(0.066)\end{array}$ & $\begin{array}{r}-0.0002 \\
(0.065)\end{array}$ \\
\hline $\bar{R}^{2}$ & 0.481 & 0.353 & 0.387 & 0.484 & 0.353 & 0.487 \\
\hline$N$ Observations & 114 & 83 & 83 & 83 & 83 & 83 \\
\hline
\end{tabular}

$*$ = Significantly different from zero at the 5 percent level.

** = Significantly different from zero at the 10 percent level.

*** = Not statistically significantly different from one at the 5 percent level. 
TABLE 5-continued

Notes: Estimation of regional effects is explained in the notes to Table 4. The remaining variables are defined in the text. Columns 2-5 are estimated using only those cities for which data are available for all of the regressors. Standard errors are in parentheses.

Sources: For earnings and cost of living, see the sources for Table 4. Population, age distribution, and mortality data are from U.S. Department of the Interior, Census Office, Twelfth Census, Population. Occupational distributions are from unpublished tabulations provided by Thomas Weiss. Climatic data were supplied by Robert Whaples from a variety of sources.

anomalous result is explained by reverse causation, with lower income causing higher infant mortality rates. None of the climatic variables is statistically significant. Inclusion of these variables again narrows the differentials between the North Central and Northeast relative to column 2 , but widens the North-South earnings gap. Controlling for amenities also lowers western earnings, causing them to fall slightly below eastern levels.

In column 5 a single explanatory variable, the rate of population growth from 1900 to 1910 (SHOCK) is added to the regression as a proxy for temporary disequilibrium. The coefficient on this variable is positive, as would be expected, but it is statistically insignificant and does not appreciably increase the explanatory power of the regression. Controlling for temporary disequilibrium also has little effect on the regional effects.

Column 6 reports the results of a combined regression including all the explanatory variables. In most cases the coefficient estimates in this regression closely resemble those in the preceding columns. Controlling for labor force composition, locational characteristics, and temporary disequilibrium neither alters the impression of earnings equalization across the Northeast and North Central regions, nor reduces the NorthSouth earnings gap. Some of the variation in earnings within the Northeast and North Central regions is explained by these factors, strengthening the earlier impression of equalization across these regions. On the other hand, it appears that after controlling for labor force composition, locational characteristics, and disequilibrium shocks, the North-South difference actually becomes larger, not smaller. The earnings gap between the West and the East is reduced modestly. Thus it appears that differences in labor force composition and location characteristics in the West may account for part of the West-East earnings gap that emerged after 1899, but that most of this must reflect differences in demand and supply conditions.

To the extent that it is possible to account for labor force heterogeneity and locational characteristics, these factors appear to reinforce rather than reverse conclusions based on the unadjusted earnings data. Because it is impossible to control completely for the effects of labor force composition, locational characteristics, and temporary shocks, conclusions based on the census earnings, data must remain tentative. There is little evidence to suggest, however, that the important features of the earnings data would be substantially affected if these other factors could be controlled for more completely. As was noted earlier, the equalization of earnings across the 
Northeast and North Central regions of the country and the North-South earnings gap are both consistent with the available evidence on occupational wage rates, indicating that these differentials are not an artifact of geographic differences in labor quality. It is also difficult to imagine what sorts of amenity variations might have existed that would offset either the apparent equalization of wages and earnings within the North, or the large North-South differentials.

\section{POPULATION REDISTRIBUTION AND LABOR MARKET INTEGRATION}

Information on population redistribution provides further confirmation of the plausibility of the earnings data. If labor supply responses were instantaneous, little additional information about market integration could be gained from an examination of population redistribution. In such a situation, there would be no relationship between earnings variations and population movements. But where adjustment takes place more gradually, it should be possible to observe labor movements from low to high earnings locations. Although the available data are less than complete, they reinforce the main conclusions of the previous section that a substantially integrated northern labor market had emerged by at least 1879 and that the increasingly unified southern labor market that was developing after 1879 remained largely distinct from this northern market.

Labor supply responses to intercity earnings variation cannot be directly observed, but changes in population between census dates provide a rough proxy for this variable. Consistent with the hypothesis of within-region integration, labor supply within both the North and South appears to have been responsive to temporary spatial disequilibrium. Between 1880 and 1890 , for example, the high level of earnings in the West North Central region coincided with a rapid influx of population. Although the population of cities in New England, the Middle Atlantic, and East North Central regions represented in the earnings data grew by about 40 percent, the population of the West North Central cities increased by nearly 115 percent. With the convergence of earnings by 1889, population growth rates in the West North Central fell to equality with other northern regions. A similar though weaker responsiveness to the intraregional differential is apparent within the South. On average, the population of cities in the South Central region grew one and a half to two times more rapidly than that of cities in the South Atlantic in the 30 years after 1880, coinciding with the declining level of earnings in the South Central toward those in the South Atlantic. ${ }^{46}$

\footnotetext{
${ }^{46}$ The difference in growth rates was smallest in the 1880 s, when the population of the South Central cities increased by 46 percent, whereas that of the South Atlantic cities increased by 33 percent. In the 1890 s the South Central cities' population increased an average of 33 percent, whereas cities in the South Atlantic averaged only a 14 percent increase. After 1900 growth rates picked up in both regions, rising to 55 percent in the South Central and 25 percent in the South Atlantic.
} 
The lack of North-South integration implied by the earnings data is supported by evidence of a small, but expanding stream of out-migration from the South. Internal migration of the native-born population cannot be traced directly, but the net migration from a region between census dates can be estimated by comparing the actual change in population with the change that would be expected based on the age structure of the population at the previous census and age-specific mortality rates for the nation as a whole. Beginning in 1880 net outmigration rates from the South hovered in the range of 10 to 20 per thousand of population, roughly comparable to the rates of net out-migration of the native-born population from the Northeast and North Central regions. By 1910 something over 800,000 southerners had migrated mainly to the Northeast or North Central regions. But the impact of southern migration into northern labor markets was dwarfed by the net increase of 11.8 million in the foreign-born population of the Northeast and North Central regions in this same time period. Thus, although higher northern earnings do appear to have attracted some southerners, this flow was far too small to have had any appreciable impact on interregional earnings differentials. Only after 1910, did rates of southern out-migration begin to rise, reaching 42 per thousand for the 1910s, and 48 per thousand in the 1920s. Although these data do indicate some labor supply response to North-South earnings differentials, the small size and limited effects of this response on the existing differentials suggest that it is most appropriate to treat northern and southern labor markets as essentially distinct. ${ }^{47}$

The movements of the foreign-born provide a highly sensitive index of economic opportunities that can be used to confirm further impressions based on the earnings data. Immigrants were motivated by a vast array of different factors, but economic considerations loomed large among them. ${ }^{48}$ Consistent with the large North-South earnings gap found earlier, immigrants generally avoided the South. In 1880, for example, the foreign-born accounted for 26.6 percent of the population of the Northeast and North Central cities included in the earnings data, compared to 14.3 percent of the population in cities in the South Central and just 6.5 percent of the population of South Atlantic cities. ${ }^{49}$ More striking, however, than these broad regional differences is the way in which the foreign-born population was distributed within each region. In the South there was an

\footnotetext{
${ }^{47}$ Eldridge and Thomas, Population Redistribution, p. 90.

${ }^{48}$ Piore, Birds of Passage; Hatton and Williamson, "What Drove the Mass Migrations?"; Dunlevy and Saba, "Nineteenth-Century European Immigration"; and Gallaway, Vedder, and Shukla, "Distribution." The literature on international migration in the late nineteenth century is huge; for a recent review with emphasis on economic causes and consequences, see Hatton and Williamson, "International Migration."

${ }^{49}$ Although the percentage foreign-born fell gradually over time, the same pattern is evident in other years. In 1920, 19.8 percent of the population of cities in the Northeast and North Central regions was foreign-born, whereas 7.3 percent of the population in South Central cities and 3.9 percent of the population in South Atlantic cities was foreign-born.
} 
extremely close correlation between real earnings and the percentage foreign-born. Between 1879 and 1909 the correlation coefficient between the log of real earnings and the percentage foreign-born ranged from 0.65 to 0.80 . Thus, to the extent that the foreign-born were attracted to the South, they appear to have gravitated to those cities in which earnings potential was highest. This suggests that, despite signs of earnings convergence across the South, market integration was not sufficiently strong to eliminate differences in economic opportunities across locations. In contrast, within the North there was essentially no relationship between relative earnings and the percentage foreign-born. Between 1879 and 1909 in the Northeast and North Central regions, the across-city correlation coefficients ranged from -0.05 to 0.05 . This lack of association between wages and immigration is precisely what one would expect if earnings were indeed effectively equalized.

\section{CONCLUSIONS}

Previous studies of labor market integration during the late nineteenth and early twentieth centuries have focused on comparisons of occupational wage rates for a small and potentially unrepresentative sample of occupations. Moreover, these studies have reached contradictory conclusions about the extent of equalization within the Northeast and North Central regions, while largely neglecting labor market trends in the South and West. This article has employed an alternative source of data, average annual earnings calculated from the census of manufacturers, to extend the scope of investigation to include all adult male manufacturing workers and all regions of the country from 1879 to 1919. Interpreted in conjunction with the data on occupational wage variation, these new data substantially strengthen and extend our knowledge about the history of labor market integration during the late nineteenth and early twentieth centuries.

The census earnings data help to resolve the conflicting evidence about wage variation within the northern part of the country. Like the Aldrich Report and Nineteenth Annual Report wage data, they suggest the existence of a well-integrated northern labor market. Although they also confirm the conclusions based on the Bulletin 18 data that there were large interregional differentials in the late 1870 s, the earnings data suggest a much more rapid convergence after this date, consistent with the presence of a well-integrated northern labor market as early as 1879. In view of the independent confirmation provided by two wage studies and the earnings data, it appears that the Bulletin 18 data overstate the extent of interregional differentials after 1879. It is possible that the absence of convergence in these wage data is a consequence of the small and potentially nonrandom sample of employers from which they were drawn.

Census earnings data also present a much more detailed picture of labor 
market developments outside the Northeast and North Central regions. They make clear what was tentatively suggested on the basis of the occupational wage data: although labor market integration was proceeding on a regional level, this process did not extend to the national level. Evidence on western labor markets is mixed, but it appears that the developments encouraging labor market integration were not yet strong enough to overcome completely the barriers of distance that separated the West from the East.

The uneven pattern of labor market integration that characterized the late nineteenth-century United States suggests the need for further investigation of the way in which labor market institutions influenced the pace and direction of labor market integration. Existing transportation and communication technologies were clearly adequate to produce a substantial degree of integration across the Northern part of the country. Indeed, earnings in this period appear substantially more uniform than they do today. On the other hand, intraregional equalization in the North and South coincided with a pronounced lack of interregional integration. As is true of labor markets today, late nineteenth-century labor markets relied largely on informal, word-of-mouth channels of communication. These informal channels of communication thus appear capable of working very effectively once established. What remains to be determined is why their establishment was so selective. 


\section{Appendix}

APPENDIX TABLE 1

GEOGRAPHIC COVERAGE AND REGIONAL DEFINITIONS

\begin{tabular}{|c|c|c|c|}
\hline New England & Middle Atlantic & East North Central & West North Central \\
\hline $\begin{array}{l}\text { Boston, MA } \\
\text { Bridgeport, CT } \\
\text { Cambridge, MA } \\
\text { Chelsea, MA } \\
\text { Fall River, MA } \\
\text { Hartford, CT } \\
\text { Holyoke, MA } \\
\text { Lawrence, MA } \\
\text { Lowell, MA } \\
\text { Lynn, MA } \\
\text { Manchester, NH } \\
\text { New Bedford, MA } \\
\text { New Haven, CT } \\
\text { Portland, ME } \\
\text { Providence, RI } \\
\text { Salem, MA } \\
\text { Somerville, MA } \\
\text { Springfield, MA } \\
\text { Taunton, MA } \\
\text { Worcester, MA }\end{array}$ & $\begin{array}{l}\text { Albany, NY } \\
\text { Allegheny, PA } \\
\text { Auburn, NY } \\
\text { Brooklyn, NY } \\
\text { Buffalo, NY } \\
\text { Camden, NJ } \\
\text { Elizabeth, NJ } \\
\text { Elmira, NY } \\
\text { Erie, PA } \\
\text { Harrisburg, PA } \\
\text { Hoboken, NJ } \\
\text { Jersey City, NJ } \\
\text { Lancaster, PA } \\
\text { New York, NY } \\
\text { Newark, NJ } \\
\text { Oswego, NY } \\
\text { Paterson, NJ } \\
\text { Philadelphia, PA } \\
\text { Pittsburg, PA } \\
\text { Poughkeepsie, NY } \\
\text { Reading, PA } \\
\text { Rochester, NY } \\
\text { Scranton, PA } \\
\text { Syracuse, NY } \\
\text { Trenton, NJ } \\
\text { Troy, NY } \\
\text { Utica, NY } \\
\text { Wilkesbarre, PA } \\
\text { Wilmington, DE }\end{array}$ & $\begin{array}{l}\text { Bay City, MI } \\
\text { Chicago, IL } \\
\text { Cincinnati, OH } \\
\text { Cleveland, OH } \\
\text { Columbus, OH } \\
\text { Covington, KY } \\
\text { Dayton, OH } \\
\text { Detroit, MI } \\
\text { Evansville, IN } \\
\text { Fort Wayne, IN } \\
\text { Grand Rapids, MI } \\
\text { Indianapolis, IN } \\
\text { Louisville, KY } \\
\text { Milwaukee, WI } \\
\text { Newport, KY } \\
\text { Peoria, IL } \\
\text { Quincy, IL } \\
\text { Springfield, IL } \\
\text { Springfield, OH } \\
\text { Terre Haute, IN } \\
\text { Toledo, OH } \\
\text { Wheeling, WV }\end{array}$ & $\begin{array}{l}\text { Davenport, IA } \\
\text { Des Moines, IA } \\
\text { Dubuque, IA } \\
\text { Kansas City, KS* } \\
\text { Kansas City, MO } \\
\text { Minneapolis, MN } \\
\text { Omaha, NB } \\
\text { St. Joseph, MO } \\
\text { St. Louis, MO } \\
\text { St. Paul, MN } \\
\text { Topeka, KS* } \\
\text { Wichita, KS* }\end{array}$ \\
\hline South Atlantic & \multicolumn{2}{|c|}{ South Central } & West \\
\hline $\begin{array}{l}\text { Atlanta, GA } \\
\text { Augusta, GA } \\
\text { Baltimore, MD } \\
\text { Charleston, SC } \\
\text { Macon, GA } \\
\text { Norfolk, VA } \\
\text { Petersburg, VA } \\
\text { Richmond, VA } \\
\text { Savannah, GA } \\
\text { Washington, DC } \\
\text { Wilmington, NC }\end{array}$ & \multicolumn{2}{|c|}{$\begin{array}{l}\text { Birmingham, AL* } \\
\text { Dallas, TX* } \\
\text { Galveston, TX } \\
\text { Houston, TX* } \\
\text { Memphis, TN } \\
\text { Mobile, AL } \\
\text { Montgomery, AL* } \\
\text { Nashville, TN } \\
\text { New Orleans, LA } \\
\text { San Antonio, TX }\end{array}$} & $\begin{array}{l}\text { Denver, CO } \\
\text { Los Angeles, CA } \\
\text { Oakland, CA } \\
\text { Portland, OR* } \\
\text { Pueblo, CO* } \\
\text { Sacramento, CA } \\
\text { Salt Lake City, UT } \\
\text { San Francisco, CA } \\
\text { Seattle, WA* } \\
\text { Tacoma, WA* }\end{array}$ \\
\hline
\end{tabular}

Notes: Cities marked with an asterisk are included in the data set beginning in 1889. Because of changes in city boundaries, Allegheny is combined with Pittsburgh and Brooklyn is reported as part of the total for New York, beginning with the census of 1904. Data on the age and sex of manufacturing wage earners are not available for Washington, DC, in 1914 and 1919, so they are not included in the sample in these years. 


\section{REFERENCES}

Atack, Jeremy, and Fred Bateman. "How Long Was the Workday in 1880?" this Journal 52, no. 1 (1992): 129-60.

Brisendon, Paul F. Earnings of Factory Workers, 1899-1927. Census Monograph 10. Washington, DC: GPO, 1929.

Brown, John C. "The Condition of England and the Standard of Living: Cotton Textiles in the Northwest, 1806-1850." this Journal 50, no. 3 (1990): 591-614.

Carter, Susan B., and Elizabeth Savoca. "Labor Mobility and Lengthy Jobs in NineteenthCentury America." this JOURNAL 50, no. 1 (1990): 1-16.

Chandler, Alfred D., Jr. The Visible Hand: The Managerial Revolution in American Business. Cambridge: Harvard University Press, 1977.

Clark, David, James Kahn, and Haim Ofek. "City Size, Quality of Life, and the Urbanization Deflator of the GNP: 1910-1984." Southern Economic Journal 54, no. 3 (1988): 701-14.

Coelho, Philip R. P., and James F. Shepherd. "Regional Differences in Real Wages: The United States, 1851-1880." Explorations in Economic History 13, no. 2 (1974): 551-91.

. "The Impact of Regional Differences in Real Wages: The United States in 1890." this JOURNAL 39, no. 1 (1979): 69-85.

Davis, Lance E. “The Investment Market, 1870-1914: The Evolution of a National Market." this Journal 25, no. 3 (1965), 355-99.

Duboff, Richard B. "The Telegraph and the Structure of Markets in the United States, 1845-1890." Research in Economic History. Vol. 8. Greenwich, CT: JAI Press, 1982.

Dunlevy, James A., and Richard P. Saba. "Nineteenth-Century European Immigration to the United States: Intended versus Lifetime Settlement Patterns." Economic Development and Cultural Change 29, no. 1 (1980): 77-90.

Easterlin, Richard A. "Estimates of Manufacturing Activity." In Methodological Considerations and Reference Tables, by Everett S. Lee et al. Vol. 1 of Population Redistribution and Economic Growth, United States, 1870-1950, edited by Simon Kuznets and Dorothy Swaine Thomas, 635-702. Philadelphia: American Philosophical Society, 1957.

Eldridge, Hope T., and Dorothy Swaine Thomas. Demographic Analyses and Interrelationships. Vol. 3 of Population Redistribution and Economic Growth, United States, 1870-1950, edited by Simon Kuznets and Dorothy Swaine Thomas. Philadelphia: The American Philosophical Society, 1964.

Engerman, Stanley, and Claudia Goldin. "Seasonality in Nineteenth-Century Labor Markets." In American Economic Development in Historical Perspective, edited by Thomas Weiss and Donald Schaefer, 99-126. Stanford, CA: Stanford University Press, 1994.

Field, Alexander James. "The Magnetic Telegraph, Price and Quantity Data, and the New Management of Capital." this Journal 52, no. 2 (1992): 401-14.

Gallaway, Lowell E., Richard K. Vedder, and Vishwa Shukla. "The Distribution of the Immigrant Population in the United States: An Economic Analysis." Explorations in Economic History 40, no. 1 (1980): 143-50.

Goldin, Claudia. Understanding the Gender Gap: An Economic History of American Women. New York and Oxford: Oxford University Press, 1990.

. "Labor Markets in the Twentieth Century." NBER Historical Working Paper No. 58, Cambridge, MA, June 1994.

Gordon, David M., Richard Edwards, and Michael Reich. Segmented Work, Divided Workers: The Historical Transformation of Labor in the United States. Cambridge: Cambridge University Press, 1982.

Haines, Michael R. "A State and Local Consumer Price Index for the United States in 1890." Historical Methods 22, no. 3 (1989): 97-105. 
Hall, Robert. "Why is the Unemployment Rate so High at Full Employment?" Brookings Papers on Economic Activity 2 (1970): 369-402.

Hatton, Timothy, and Jeffrey G. Williamson. "What Drove the Mass Migrations from Europe in the Late Nineteenth Century." Population and Development Review 20, no. 3 (1994): 533-60.

. "International Migration 1850-1939: An Economic Survey." In Migration and the International Labor Market, 1850-1939, edited by Timothy J. Hatton and Jeffrey G. Williamson, 3-32. London and New York: Routledge, 1994.

Jacoby, Sanford M., and Sunil Sharma. "Employment Duration and Industrial Labor Mobility in the United States, 1880-1980." this JourNaL, 52, no. 1 (1992): 161-79.

James, John A. Money and Capital Markets in Postbellum America. Princeton, NJ: Princeton University Press, 1978.

"Job Tenure in the Gilded Age." In Labour Market Evolution: The Economic History of Market Integration, Wage Flexibility, and the Employment Relationship, edited by George Grantham and Mary MacKinnon, 185-205. London and New York: Routledge, 1994.

Long, Clarence D. Wages and Earnings in the United States, 1860-1890. NBER General Series No. 67. Princeton: Princeton University Press, 1960.

McCloskey, Donald N. The Extent of the Market and the Faculty of Speech. Photocopy, University of Iowa, Department of History (n.d.).

Marshall, Alfred. Principles of Economics, 9th (variorum) ed. Annotated by C. W. Guillebaud. London: Macmillan and Co., 1961.

Montgomery, Edward. "Evidence on Metropolitan Wage Differences across Industries and over Time." Journal of Urban Economics 31, no. 1 (1992): 69-83.

Nelson, Daniel. Managers and Workers: Origins of the New Factory System in the United States, 1880-1920. Madison: University of Wisconsin Press, 1975.

Piore, Michael J. Birds of Passage: Migrant Labor in Industrial Societies. Cambridge: Cambridge University Press, 1979.

Rees, Albert. Real Wages in Manufacturing, 1890-1914. NBER, General Series No. 70, Princeton: Princeton University Press, 1961.

Roback, Jennifer. "Wages, Rents, and the Quality of Life." Journal of Political Economy 90, no. 6 (1982): 1257-78.

Rosenbloom, Joshua L. "One Market or Many? Labor Market Integration in the Late Nineteenth-Century United States." this Journal 50, no. 1 (1990): 85-107.

. "Occupational Differences in Labor Market Integration: The United States in 1890." this Journal 51, no. 2 (1991): 427-39.

Rosenbloom, Joshua L., and William A. Sundstrom. "The Decline in Hours of Work in US Labour Markets." In Labour Market Evolution: The Economic History of Market Integration, Wage Flexibility and the Employment Relationship, edited by George Grantham and Mary MacKinnon, 161-84. London and New York: Routledge, 1994.

Snowden, Kenneth A. "Mortgage Rates and American Capital Market Development in the Late Nineteenth Century." this Journal 47, no. 3 (1987): 671-92.

Stover, John F. American Railroads. Chicago: University of Chicago Press, 1961.

Sundstrom, William A. "Internal Labor Markets Before World War I: On-the-Job Training and Employee Promotion." Explorations in Economic History 25, no. 4 (1988): 424-45.

Sundstrom, William A., and Joshua L. Rosenbloom. "Occupational Differences in the Dispersion of Wages and Working Hours: Labor Market Integration in the United States, 1890-1903." Explorations in Economic History 30, no. 4 (1993): 379-408.

Taylor, George Rogers, and Iren D. Neu. The American Railroad Network, 1861-1890. Cambridge, MA: Harvard University Press, 1956.

U.S. Congress. House of Representatives. Report on the Statistics of Wages in Manufacturing with Supplementary Reports, by Joseph D. Weeks. House Misc. Doc. 42. Vol. 13, Pt. 20. 47th Cong., 2nd sess. Washington, DC: GPO, 1886. 
U.S. Congress. Senate. Retail Prices and Wages. Senate Report no. 986. 52nd Cong., 1st sess., 3 parts. Washington, DC: GPO, 1892.

U.S. Department of Commerce. Historical Statistics of the United States: Colonial Times to 1957. Washington, DC: GPO, 1960.

U.S. Department of Commerce and Labor. Nineteenth Annual Report of the Commissioner of Labor, 1904: Wages and Hours of Labor. Washington, DC: GPO, 1904.

U.S. Department of Commerce and Labor. Bureau of the Census. Manufactures, 1905. Pt. 2. States and Territories. Washington, DC: GPO, 1907.

. Thirteenth Census of the United States, 1910. Vol. 10. Manufactures, 1909. Reports by States with Statistics for Principal Cities. Washington, DC: GPO, 1912.

Census of Manufactures, 1914. Vol. 1. Reports by States with Statistics for Principal Cities and Metropolitan Districts. Washington, DC: GPO, 1918.

. Fourteenth Census of the United States, 1920. Vol. 9. Manufactures, 1919. Reports for States, with Statistics for Principal Cities. Washington, DC: GPO, 1923.

U.S. Department of Interior. Census Office. Twelfth Census, 1900. Population. Pt. 1. Washington, DC: GPO, 1901.

. Twelfth Census of the United States, 1900. Manufactures. Pt. 2. States and Territories. Washington, DC: GPO, 1902.

U.S. Department of Labor. "Wages in the United States and Europe, 1870-1898." Bulletin no. 18. Washington, DC: GPO, 1898: 665-93.

U.S. Department of Labor. "Retail Prices 1890 to June 1912." Bulletin no. 106. Washington, DC: GPO, 1912.

U.S. Department of Labor. "Retail Prices, 1907 to December 1914." Bulletin no. 156. Washington, DC: GPO, 1915.

U.S. Department of Labor. "Retail Prices, 1913 to December 1920." Bulletin no. 300. Washington, DC: GPO, 1922.

Williamson, Jeffrey G. "Was the Industrial Revolution Worth It? Disamenities and Death in 19th Century British Towns." Explorations in Economic History 19, no. 3 (1982), 221-45.

Wilson, Lonny L. "Intercity Wage and Cost of Living Differentials in the United States, 1889-1939." Ph.D. diss., University of Iowa, 1973.

Wright, Gavin. Old South, New South: Revolutions in the Southern Economy Since the Civil War. New York: Basic Books, 1986.

. "Labor History and Labor Economics." In The Future of Economic History, edited by Alexander J. Field, 313-48. Boston: Kluwer-Nijhoff, 1987.

. "Postbellum Southern Labor Markets." In Quantity and Quiddity: Essays in U.S. Economic History, edited by Peter Kilby, 93-134. Middletown, CT: Wesleyan University Press, 1987. 